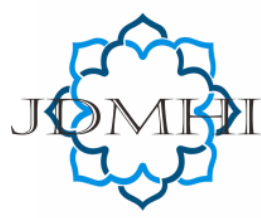

email: jdmhi@walisongo.ac.id

Journal of Digital Marketing and Halal Industry

ISSN: 2716-4810 (print) ISSN: 2716-4802 (online)

\title{
Implementation of Total Quality Management in Creating Competitive Advantage
}

\section{Muchamad Fauzi}

Universitas Islam Negeri Walisongo, Semarang, Indonesia

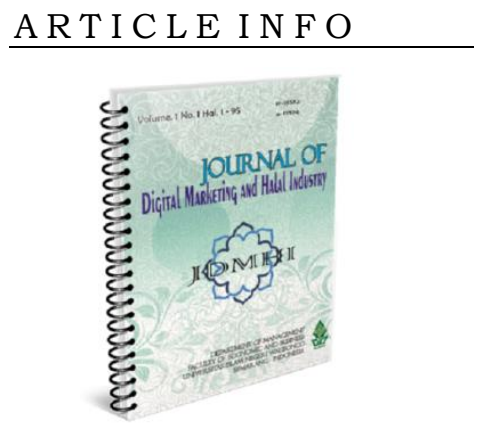

Article history:

Received 3 June 2021

Accepted 22 September 2021

Published 30 October 2021

Keywords:

Halal, TQM,Competitive

Advantage

\section{A B S T R A C T}

Total Quality Management is an important business-level strategy because it can create a competitive advantage. This study aims to analyze the Effect of Total Quality Management on employee creativity, performance, and Competitive Advantage. This study examines Total Quality Management as a potential source of competitive advantage. This research shows that most features are generally related to Total Quality Management, such as quality training, process improvement, an open culture, employee empowerment, and executive commitment can produce benefits. This research is quantitative research using primary data. The statistical tool used is regression at a $5 \%$ significance level. The research results indicate that all hypotheses are accepted. It means that Total Quality Management affects employee's creativity, performance, and competitive advantage. In addition, based on the theory of competitive advantage, corporate resource-based theory, and system theory. It can be concluded that Total Quality Management can produce cost-based benefits or differentiation to encourage the success of Total Quality Management in achieving competitive advantage.

@2021 Journal of Digital Marketing and Halal Industry

\section{Introduction}

In recent years, Total Quality Management (TQM) has become a global concern in line with changes in the global economy and the strength of market demand. Unfortunately, the traditional control methods applied in the industry have not produced the expected results, requiring the industry always to improve the performance of both products, employee performance, and competitiveness to have a competitive advantage. Nevertheless, companies that have halal certification from the Indonesian Ulema Council (MUI) believe that $\mathrm{SJH}$ is part of the implementation of

* Corresponding author.email: much_fauzi@walisongo.ac.id DOI: http://dx.doi.org/10.21580/jdmhi.2021.3.2.8644 
TQM can contribute to organizational competitiveness (Fauzi et al., 2020).

TQM is an important business-level strategy because it can create a competitive advantage by creating value for the company. The resulting product is superior to its competitors, product sustainability, profits are above average, and competitors cannot imitate the advantages of their products (J. B. Barney, 1991). Market competition between companies that produce cosmetics is experiencing increasingly competitive competition, and the target market is Muslim consumers. As evidence of Muslim market share is many types of cosmetics produced in the country and foreign production circulating in Indonesia using the halal label. Meanwhile, the circulation of cosmetic products can affect consumer interest. Therefore, the use of a cosmetic product is no longer just to fulfill wants, but because cosmetics are a need (needs) at this time. So Total Quality Management was born because of the revolution.

Cosmetic companies that have obtained halal certification from the Indonesian Ulema Council (MUI) for products produced are required to implement a halal assurance system that can consistently ensure the

\section{Table 1.}

Consumption of the Cosmetics Sector



\begin{tabular}{|c|}
\hline $\begin{array}{c}\text { Indonesia imports } \\
\$ \text { billions, } 2017\end{array}$ \\
\hline 16.9 \\
0.1 \\
1.0 \\
1.1 \\
0.6 \\
19.7
\end{tabular}

sustainability of the halal production process. The Halal Assurance System (SJH) elaborates, connects, accommodates, and integrates Islamic sharia concepts, especially those related to halal haram, business ethics, and overall management, procedures, and mechanisms for planning, implementing, and evaluating a series of products or processed materials to be consumed (Amalia, 2019; Fataron \& Rohmah, 2020).

The Halal Assurance System ( $\mathrm{SJH}$ ) is always based on Islamic law and overall management, from planning to evaluation procedures. Which refers to the basic concept of Total Quality Management (TQM), As one of the efforts made by researchers to determine the application of TQM in cosmetic companies that have received halal certification by combining the concepts proposed by Tjiptono, Fandy and Anastasia, Diana, and LPPOMUI (Afendi, 2020; Puspaningtyas \& Sucipto, 2021; Putri et al., 2021). Indonesia is predominantly Muslim, and halal is used in using products. Data from IHLC (Indonesia Halal Lifestyle Center) shows the highest domestic consumption of the cosmetics sector compared to other sectors, as shown in table 1.1. as follows:

Source: IHLC 2019

Similarly, the number of cosmetic products

compared to the number of other products is http://journal.walisongo.ac.id/index.php/JDMHI/index DOI: http://dx.doi.org/10.21580/jdmhi.2021.3.2.8644 
140,505 Products as shown in Figure 1.3 as follows:

Figure 1.2

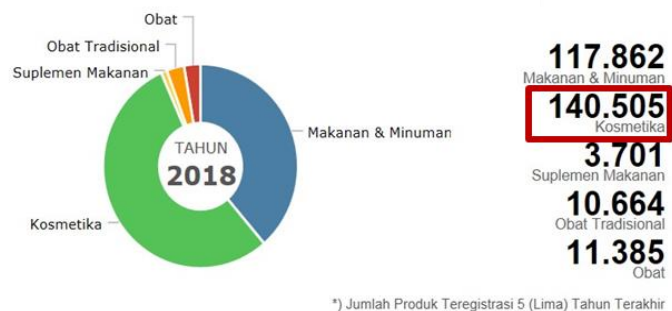

Source: BPOM, LPPOM MUI Data - March 2018

Previous research examining the effect of TQM on employee performance found a positive relationship between TQM practice and performance. As researched by Vera Sylvia S, Therese, Wardani et al. 1, Tinekee et al. l, Al Shobaki et al. 1, Zehir Hendricks and Singhal, Berquist and Ramsing, Tena et al.But Mohrman's research. Susanto found that TQM did not affect employee performance. Laili stated that TQM on employee performance has an effect of $10 \%$ and Enny's research. So from the differences in the findings of this study, it is necessary to study whether TQM can affect employee performance to create a competitive advantage in the halal industry (Latifah et al., 2021; Widiyono, 2021).

\section{Literature Review}

"TQM is considered the integration of various processes that characterize the dynamics of behavior of an organization as a total system (socio-technical), in which all activities carried out are directed to meet customer requirements with efficiency and effectiveness. Zaire and Simintiras (1991) have proposed this point of view. They state that Total Quality Management combines socio-technical processes to get things right (externally). Everything is right (internally) the first time and all the time, with economic viability considered at every stage of each process. Thus TQM is based on the quest for progress and continuous improvement. In cost, reliability, quality, innovative efficiency, and business effectiveness (Aimi et al., 2021; El-Garaihy et al., 2022).

According to M.N. Nasution, the benefits of Total Quality Management can be grouped into two, namely improving the competitive position and increasing output that is free from damage, M. Nasution (2001). The advantages of companies that implement total quality management are:

a. Total Quality Management develops the concept of quality with a totality approach. When viewed from the consumer's point of view, quality is defined as conformity.

b. There are continuous changes and improvements by implementing Total Quality Management. Therefore, companies must always learn and change to improve or improve their abilities.

c. The existence of prevention efforts means that from product design, the process to final product to produce a good product without any defective products (zero defects) so that the company can reduce costs (cost reduction), avoid waste and produce products effectively and efficiently and in the end can increase profit for the company

\section{Economic Value of TQM}

Resource theory provides a useful perspective 
on this issue, starting with the notion of resource heterogeneity, namely, that firms hold different portfolios of resources. These differences result in variability in performance across firms (Wernerfelt, 1984; (J. B. ( Barney, 1986); Peteraf, 1993).

Although firms may seek to emulate the resources of successful competitors or imitate benefits, their resources remain heterogeneous because they cannot imitate, created by 'isolation mechanisms' (Rumelt, 1984) such as:

a. Time compression diseconomies resources may require long-term accumulation before achieving value (e.g., learning, experience, or proficiency in a skill);

b. Historical uniqueness (first-mover advantage) - the resource may be initially acquired in a unique state and cannot be replicated;

c. Resource linkage - a firm can obtain a valuable resource, while a competitor only finds its success depends on a few complimentary resources that the firm cannot obtain;

d. Causal ambiguity - the company may not be able to determine the link between the company's resources and its success; and

e. Social complexity - a company's success may result from social phenomena too complex for managers to understand or manage (Lieberman and Montgomery, 1988; Dierickx and Cool, 1989; (Barney, J. B., \& Zajac, 1994).

TQM generates value through a variety of benefits: increased understanding of customer needs; increased customer satisfaction; improved internal communication; better problem solving; greater employee commitment and motivation; stronger relationships with suppliers; fewer errors; and reducing waste (Juran, 1988; Schmidt and Finnigan, 1992; Spechler, 1991).

The benefits of TQM as found by Farjara Mita (2014), there is an effect of implementing total quality management on the quality of human resources, including:

a. The role of employees is tenacity in fostering creativity, sincerity in carrying out programs, the ability to develop themselves, confidence, and trust in the benefits of total quality management.

b. The leadership role is active participation, openness in information, close indifference to organization members, and has leadership qualities.

c. Relationships with leaders and employees are linguistic in action, togetherness in analysis, compatibility of steps and actions, volunteerism in cooperation.

d. The organizational aspect is the integration of individuals in the system. This relates to a sense of belonging, completeness of facilities, work programs, involvement in actions, and reward systems.

e. Environmental aspects are work discipline, suitability of situations and conditions, environment and work processes, and workplace comfort.

\section{Evolution of TQM}

The evolution of TQM results from the four major eras outlined by Garvin (Husny et al., 2018; Kuzaiman et al., 2018). First, it describes an evolutionary process in which quality has moved from the early stages of checking, sorting, and correcting standards to the second stage of the era of developing quality manuals and controlling process performance. The third stage is to develop a system for third-party 
certification, a comprehensive manual system including areas of the organization other than production, and to use standard techniques such as SPC. All four TQMs are strategic and based on continuous improvement as a driving force. Sink identified the main factors behind the need for TQM as the global economy; complex and dynamic technology; complex and dynamic resources; customer orientation and expectations; complex and dynamic task environment; and analyzing solution spaces and opportunities.

According to Sink, TQM has evolved from these five checkpoints:

a. Selection and management of upstream systems.

b. Incoming quality assurance.

c. Processing management and quality assurance.

d. Quality assurance out.

e. Proactive assurance, whereby an organization's systems meet needs, specifications, requirements, customer values, wants, and expectations.

\section{TQM And Halal Assurance System (SJH)}

The halal assurance system refers to Total Quality Management (TQM), an integrated quality management system that emphasizes quality control in every line (Firdiansyah et al., 2021; Mustun, 2021; Noordin et al., 2009). As stated in the research of Fotopoulos et al., TQM is the basis of copyright regarding production quality assurance. Regulations issued by LPPOM MUI with SK No: SK 13/Dir/LPPOM.MUI/III/13, has required that companies that have obtained MUI halal certificates implement the 23000 Halal Assurance System (SJH). The aim is to ensure and guarantee that the products produced are halal and not contaminated with najis.
Implementing the Halal Assurance System (HAS) can be regarded as a form of TQM implementation by building the company's commitment to producing halal products. In this way, companies that will carry out halal certification form a halal management team in their company. And this team consists of various parts involved in critical activities and already have the competencies needed to carry out their duties to maintain halal materials, production processes, and facilities used.

The halal assurance system has a document containing a summary that includes, among others:

a. Top management must establish and socialize the Halal Policy.

b. Materials used in manufacturing products must not come from unclean/unclean materials.

c. Top management must establish a Halal Management Team that includes all parties involved in critical activities

d. The company must have a training implementation procedure.

e. The product name may not use a name that refers to something forbidden or worship that is not following Islamic sharia.

f. Production facilities must ensure no crosscontamination with unclean/unclean materials.

g. Companies must have written procedures regarding the implementation of critical activities, namely activities in the production supply chain

h. Companies must have written procedures to ensure traceability of certified products originating from materials that meet the criteria and are produced in production facilities that meet the criteria, LPPOM MUI

i. The company must have written 
procedures for handling products that do not meet the criteria.

j. The company must have a written procedure for internal auditing the implementation of HAS (Halal Assurance System).

k. Top Management/its representatives must conduct a management review at least once a year

\section{Competitive Advantage}

There are two complementary models of competitive advantage based on economic theory (Conner, 1991; Porter, 1980, 1985). First, market-based models focus on cost and differentiation. They argue that the environment favors inefficient firms or that do not offer products for which consumers are prepared to pay a premium. The theory of advantage is primarily driven by external factors (opportunities, threats, and industry competition) and, as Porter (1985) points out, maintaining an advantage means presenting competitors with 'a target movement. "The second model is centered on the firm's resources and is driven by factors that are internal to the firm. For example, resources that provide operational excellence or assistance create a superior market position enabling the firm to generate superior returns. In the resource-based theoretical model, the sustainability of the advantage depends on nonexistent competitors being able to imitate the resource.

\section{Implementation of TQM}

TQM is carried out with a systematic, pragmatic, well-thought-out approach. Sink has suggested the following approaches to TQM design, development, and implementation:
Stage 0: understand the organizational system.

Stage 1: develop a strategic plan for the TQM effort.

Stage 2: planning assumptions.

Stage 3: define strategic objectives.

Stage 4: define tactical objectives.

Stage 5: implementation planning.

Stage 6: project management.

Stage 7: measurement and evaluation.

Stage 8: evaluation, accountability, follow-up, ensure effectiveness in application.

The implementation of TQM is not an easy task as it requires a total change of organizational culture, a shift of responsibility to management, and continuous participation of all in the quality improvement process. Matherly and Lasater point out the obstacles in implementing TQM in hospitals as:

1. Lack of manager participation;

2. Overlapping leadership responsibilities;

3. Limited resources;

4. Fear of change;

5. Overworked.

To adopt the TQM philosophy, the following approaches are suggested:

(1) Develop a vision: Top leadership should focus on how the organization can best meet the needs of its external and internal customers. It should promote quality improvement goals, strategies, and projects. A clear and well-projected vision will help organize resources and focus on goals to achieve results; it should reflect the total commitment. 
(2) Promote policies on quality: People follow policies, for better or for worse. To ensure that all employees understand top management's behavior, a clear and concise policy on quality needs to be formulated. It is necessary to state that the level of defect or error is acceptable. The policy also needs to state the relationship between the company and the customer. The policy should be direct and concise and clearly define management's commitment to quality.

(3) Creating a total quality-oriented culture: Attempts to adopt TQM will only succeed if the cultural change occurs. This can be achieved by focusing on the cultural traits within the organization. Follow the essential steps to get a culture change:

a. Operating policies, procedures, and business processes should all emphasize quality.

b. Everyone in the organization should clearly understand the importance of quality in achieving their business goals.

c. People at every level must be aware of customer requirements and needs.

d. The organizational structure should allow for continuous improvement.

e. There should be an integration of internal and external customer requirements in the business plan

f. The use of customer-based performance measures is important.

g. There is a need to develop strong lines of communication.

h. Customer commitment must be fostered.

i. The emphasis on customer-oriented values and beliefs must be supported by top management.

\section{The Method, data, and analysis}

This study used a qualitative approach by producing descriptive data in words in the form of writing from the behavior being studied. A qualitative approach is a complex picture examining words, detailed reports of the respondent's viewpoint, and conducting case studies of natural situations. The paradigm used in this research is the constructivist paradigm. The constructivist paradigm is a paradigm that is almost the antithesis of the understanding that places observation and objectivity in discovering a reality or science. The data collection technique used in this research is document study because it is necessary to analyze content related to research. Document study itself is a qualitative data collection method by viewing or analyzing documents created by the subject himself or others. Researchers do this to obtain accurate data results according to the source. The data analysis technique used a qualitative approach with descriptive analysis.

\section{Result and Discussion}

Basically, TQM can produce a competitive advantage. Given that TQM as a strategy carried out by the company is not just a tool. Gehani (1993) sees that TQM provides a unifying framework that brings various "management practices" to bear together.

As indicated, there is agreement among (Crosby, 1991; Deming, 1982; Feigenbaum, 1990) Ishikawa, and Juran that quality management aims to reduce costs and increase customer satisfaction. These ideas fit well with the market-based view of competitive advantage arising from superior cost structures 
or the ability to differentiate products in ways that add value to customers; e.g., reduced rework and savings that arise from improving product quality can help lower a company's cost structure, and by producing products that better satisfy customer requirements, there is potential for differentiation.

Reed et al. (1996) argue that the content of TQM includes four main componentsgenerating market advantage, increasing product design efficiency, increasing product reliability, and increasing process efficiencyand they conclude that a fit is needed between company orientation, company environment, and the four main components of TQM to improve performance. Company performance. For example, a customeroriented company operating in an environment with a high degree of uncertainty should focus on creating market advantages and product design efficiencies to increase revenue and reduce costs, respectively.

For firms with an operating orientation in a low-uncertainty environment, concentration on product reliability and process efficiency will result in increased revenues and reduced costs, respectively. In addition, market advantage arises from a market-driven existence (Day, 1990), which provides the potential for product differentiation through better identification of customer needs and anticipating competitors' product offerings. Likewise, companies that can offer products with higher reliability than those offered by competitors are, in effect, differentiating their product offerings to customers.

Better product design efficiency reduces costs by eliminating non-value-adding parts, making the product easier to manufacture. And, increased process efficiency, arising from experience and learning, also reduces costs. Therefore, we can again conclude that TQM has the potential to generate a competitive advantage.

As the findings of research on the implementation of TQM in creating a competitive advantage in the halal cosmetics industry in Central Java resulted in the following:

\section{The Effect of TQM on Employee Creativity}

The results showed that TQM using halal indicators had a significant positive effect on employee creativity. resulted in a CR value of $2.022>1.98$ with a significance value of 0.043 $<0.05$. This means that the implementation of TQM implemented by the company can increase employee creativity. Creativity is rooted in individual or employee capabilities related to personality, cognitive abilities, and problem-solving styles. This capability is raised and encouraged by implementing qualityoriented TQM carried out by the company. Just like the study conducted by Behesthifar Malikeh, Elaheh Zare (2013) that an organization must understand employee behavior and create a culture of creativity within the organization that has been determined by top management, the results of the study show that employee creativity is a long process, and is not limited by place. And time, so that the creativity of employees in an organizational process must be supported by top management. There is a positive and significant relationship between creativity on employee performance and competitive advantage.

\section{The Effect of TQM on Employee Performance}

This shows that TQM using halal indicators is 
statistically proven to affect employee performance significantly. resulting in a CR value of $2.124>1.98$ with a significance value of $0.034<0.05$. This finding indicates that cosmetic companies implementing TQM in the production process can produce high performance. Improve employee performance. Research conducted by Therese (2003) found that support from the organization or management and employees is significant and can create a competitive advantage. Likewise, research by Munizu Musran (2013) also found findings that the implementation of TQM has a significant effect on competitive advantage and performance. Likewise, with the research results by Amie Nadia, et al. (2016). Khaiulnizam Zahari Mohd, and Noor Hayati Zakuan (2017) found the same conclusion that there is evidence that TQM has a positive and significant relationship to employee performance.

\section{The Influence of Employee Performance on Competitive Advantage}

The results obtained indicate that employee performance has a significant positive effect on competitive advantage. resulting in a CR value of $2.163>1.98$ with a significance value of $0.031<0.05$. This means that increasing employee performance will also lead to an increase in competitive advantage. The company's competitive advantage in its activities needs to utilize its human resources by prioritizing a healthy way of competing with other companies. Employees who work with all their abilities will produce maximum productivity, high performance, and better corporate responsibility, which in the end will have an impact on competitive advantage

\section{Conclusion}

This research shows that most features are generally related to Total Quality Management, such as quality training, process improvement, an open culture, employee empowerment, and executive commitment can produce benefits. This research is quantitative research using primary data. The statistical tool used is regression at a $5 \%$ significance level. The research results indicate that all hypotheses are accepted. It means that Total Quality Management affects employee's creativity, performance, and competitive advantage. In addition, based on the theory of competitive advantage, corporate resourcebased theory, and system theory. It can be concluded that Total Quality Management can produce cost-based benefits or differentiation to encourage the success of Total Quality Management in achieving competitive advantage.

\section{Recommendations}

There are deficiencies in this study. It is hoped that further research can carry out a further analysis because the results of our analysis can be developed into more comprehensive research through in-depth data collection techniques.

\section{References}

Afendi, A. (2020). The Effect of Halal Certification, Halal Awareness and Product Knowledge on Purchase Decisions for Halal Fashion Products. Journal of Digital Marketing and Halal 
Industry, 2(2), 145. https://doi.org/10.21580/jdmhi.2020. 2.2.6160

Aimi, S., Zainal, S., Jalil, S. A., \& Taib, M. N. (2021). A Conceptual Framework for Understanding the Potential Economic Impact of Halal Food Testing in Halal Supply. Advances in Business Research International Journal, 7(2), 276-287.

Amalia, F. (2019). The Role of Religiosity on Halal Product Purchasing Decision Case Study: Wardah Cosmetics. Journal of Digital Marketing and Halal Industry, 1(1), 19-24.

https://doi.org/10.21580/jdmhi.2019. 1.1.4774

Barney, J. B., \& Zajac, E. J. (1994). Competitive organizational behavior: toward an organizationally based theory of competitive advantage. Strategic Management Journal.

Barney, J. B. (1991). Firm resources and sustained competitive advantage. Journal of Management.

Barney, J. B. (. (1986). Organization culture: can it be a source of sustained competitive advantage? Academy of Management Review.

Crosby, P. B.-20. (1991). Quality Management in Emerging Nations. Productivity, 32(3).

Deming, W. E. (1982). "Quality, Productivity and Competitive Position",. Massachusetts Institute of Technology Centre for Advanced Engineering Study,.

El-Garaihy, W. H., Badawi, U. A., Seddik, W. A. S., \& Torky, M. S. (2022). Design, building and validating a measuring scale for the supply chain management practices of industrial organizations by assessing their efficiency on SCM measures. Uncertain Supply Chain Management, $\quad 10(1), \quad 49-68$. https://doi.org/10.5267/j.uscm.2021.1 0.010

Fataron, Z. A., \& Rohmah, H. (2020). Effect Analysis of Trust, Ease, Information Quality, Halal Product on Online Purchase Decision of 2016-2018 Batch Students of Islamic Economics Study Program in UIN Walisongo at Shopee Marketplace. Journal of Digital Marketing and Halal Industry, 1(1), 1. https://doi.org/10.21580/jdmhi.2019. 1.1.4772

Fauzi, M., Azizah, A. N., \& Nurfauziyah, L. (2020). The Concept of Ifta 'in Establishing Halal Law (Study of Usul fiqh on Legal Determination Methods). Journal of Digital Marketing and Halal Industry, $\quad 1(1), \quad 83$. https://doi.org/10.21580/jdmhi.2019. 1.1.4776

Feigenbaum, A. V. (1990). Total Quality Developments into the 1990s - An International Perspective, an IFS Executive Briefing. IFS Publications,.

Firdiansyah, F. A., Rosidi, A., \& Iman, A. K. N. (2021). IMPLEMENTATION OF GREEN SUPPLY CHAIN MANAGEMENT IN HALAL SUPPLY CHAIN MANAGEMENT - A CONCEPTUAL MODEL. Islamiconomic: Jurnal Ekonomi Islam Volume, 12(1), 1-22.

Husny, Z. J. M., Tan, M. I. I., Sulong, N., Yusof, N. S., \& Mazlan, M. N. A. (2018). TECHNOLOGY REQUIREMENT 
FOR HALAL QUALITY CONTROL. Journal of Fundamental and Applied Sciences, $\quad 4(1), \quad 9-10$. http://dx.doi.org/10.4314/jfas.v10i1s.7

Kuzaiman, N. A., Zainuddin, A., Mohd Salleh, N. A., Kasolang, S., \& Rashid, A. A. (2018). Green lean TQM Islamic Process Management Practices in Malaysian food companies. Journal of Mechanical Engineering, 5(Specialissue4), 12-22.

Latifah, S. N., Wijayanti, W., \& Utami, E. M. (2021). The Effect of the Application of Total Quality Management, Supply Chain Management, and Entrepreneurship Orientation on Operational Performance. Journal of Digital Marketing and Halal Industry, 3(1), 63-72.

https://doi.org/10.21580/jdmhi.2021. 3.1.7441

Mustun, Z. K. (2021). Halal food certification and business excellence: A conceptual paper. Journal of Emerging Economies and Islamic Research Halal, 9(3), 98-116.

Noordin, N., Md Noor, N. L., Hashim, M., \& Samicho, Z. (2009). Value chain of Halal certification system: A case of the
Malaysia Halal Industry. Proceedings of the European and Mediterranean Conference on Information Systems, EMCIS 2009.

Puspaningtyas, S. D., \& Sucipto, S. (2021). Integration of Halal Assurance System (HAS) in the Integrated Management System (IMS) to support food industry performance: A review. IOP Conference Series: Earth and Environmental Science, 733(1). https://doi.org/10.1088/17551315/733/1/012045

Putri, H. M., Dachyar, M., \& Nurcahyo, R. (2021). Measuring service quality of halal certification in Indonesia food industry using Fuzzy-SERVQUAL method for service quality improvement. Proceedings of the International Conference on Industrial Engineering and Operations Management, 34, 1782-1791.

Widiyono, D. (2021). Religiosity of Dominant in Factors Implementation of TQM Teachers: Study in Vocational School. Advances in Social Science, Education and Humanities Research, 574(Iset 2020), 8893. 